\title{
Prevalence of xerostomia on type 2 diabetes mellitus in Hajj Hospital Surabaya
}

\author{
Kus Harijanti, ${ }^{1}$ Bagus Soebadi, ${ }^{1}$ and Irvanda Mulyaningsih ${ }^{2}$ \\ ${ }^{1}$ Departement of Oral Medicine \\ ${ }^{2}$ Student \\ Faculty of Dentistry Airlangga University \\ Surabaya - Indonesia
}

\begin{abstract}
Diabetes Mellitus (DM) is a chronic disorder of carbohydrate, fat and protein metabolism. A defective or deficient of the insulin secretory, which is translated into impaired carbohydrate (glucose) use, is characteristic feature of DM, as the resultant is hyperglycemia. There is variability among patients, however, morphologic changes are likely found in arteries (atherosclerosis), basement membrane of the blood vessel wall tissues (micro angiopathy), kidneys (diabetic nephropathy), retina (retinopathy), nerves (neuropathy) and other tissues. If it involves salivary glands, the clinical sign is xerostomia. The type 2 of DM is caused by a combination of peripheral resistance to insulin action and an inadequate secretory response of the pancreatic $\beta$-cell. Approximately $80 \%$ to $90 \%$ of patients have type 2 diabetes. The purpose of this study was to determine the prevalence of xerostomia and its relation with level of blood glucose in type 2 DM. The data was taken using cross sectional method on the diabetic patients of Internal Medicine clinic, Hajj Hospital Surabaya from February to March 2006. The result that showed among 50 samples of the type 2 DM, the prevalence of xerostomia were 38 patients (76\%). Most of the patients (32 patients $=84 \%$ ) on bad regulation of DM with level of fasting glucose $\geq 126 \mathrm{mg} / \mathrm{dl}$ and level of post prandial glucose $\geq 180 \mathrm{mg} / \mathrm{dl}$. The study showed that bad regulation of type 2 DM could develop complication on salivary glands, with xerostomia as the clinical sign.
\end{abstract}

Key words: xerostomia, diabetes mellitus type 2

Correspondence: Kus Harijanti, c/o: Bagian Oral Medicine, Fakultas Kedokteran Gigi Universitas Airlangga. Jln. Mayjend. Prof. Dr. Moestopo No. 47 Surabaya 60132, Indonesia.

\section{INTRODUCTION}

Diabetes Mellitus (DM) is a metabolic disease with clinical feature such as hyperglycemia and glycosuria. It may also appear with polyuria, polyphagia or decrease of body weight. The symptoms are chronic or asymptomatic. ${ }^{1}$

The two metabolic defects that characterized type $2 \mathrm{DM}$ are: 1 ) decrease ability of peripheral tissue to respond insulin (insulin resistance) and 2) $\beta$-cell pancreatic dysfunction that is manifested as inadequate insulin secretion, and the cardinal manifestation of diabetes mellitus is hyperglycemia. In most cases, the first process is insulin resistance and is followed by increasing degrees of $\beta$-cell pancreatic dysfunction. Insulin resistance is defined as resistance to the effects of insulin on glucose uptake, metabolism or storage. These are the characteristic feature of most patients with type 2 DM. Insulin resistance often detected 10 to 20 years before the onset of DM in predisposed individual (e.g., offspring of type 2 diabetics). ${ }^{2,3,4}$

The eighty percent to $90 \%$ of the DM patients are the type 2 . The onset is slow and usually occurs on patients over 40 years old with obesity frequently obese. However, with the increase of obesity and sedentary lifestyle in our society, type 2 diabetes is now found in children and adolescents with increasing frequency. ${ }^{2,3}$
Oral diabetic is a manifestation of DM in the mouth, present on patients with uncontrolled or undiagnosed DM. There are differences in reaction and ability between normal person and patients with DM toward injury, infection and local irritation in the mouth. The oral diabetic has various manifestations in the mouth, such as xerostomia diabetic. Xerostomia is defined if unstimulated saliva secretion is less or equal to $0.15 \mathrm{ml} / \mathrm{min}$. The term is used to encompass the spectrum of oral complaints voiced by patients with dry mouth. Patients complain of difficulty chewing, swallowing and speaking. Many patients reported that they to need fluids while eating to ease the swallowing process or enable to swallow dry foods. ${ }^{3,5}$ Xerostomia diabetic is permanent condition, which can not be treated by drinking-water or administering sialogog. ${ }^{6}$

The aim of the study was to determine the prevalence of xerostomia and its relation with level of blood glucose in type 2 DM at Hajj Hospital Surabaya.

\section{MATERIAL AND METHOD}

The research had been done at Interne clinic of Hajj Hospital on February until March 2006 by cross-sectional method and selective random sampling. Criterias of the 
sample were 1) patient with type $2 \mathrm{DM}, 2$ ) the age over 40 years old, 3) non smoking, 4) non alcoholic, 5) non dental prosthetic user 6) patient did not undergo radiation treatment, and 7) for women, samples they were not menopause. The primary data was obtained by measuring unstimulated saliva secretion of the patients and answering questioner. The secondary data was taken from the registered medical status.

The diagnosis of diabetes is established by noting elevation of blood glucose. A fasting blood glucose level of type $2 \mathrm{DM}$ is more than $126 \mathrm{mg} / \mathrm{dl}$, and 2 hours post prandial blood glucose level is more than $200 \mathrm{mg} / \mathrm{dl}$.

One hour before collecting the saliva, patients had no meal. While the patients were waiting, we checked the fasting and 2 hours post prandial blood glucose level from the medical status. After that, we examined the intra oral mucosa and anamnesed the oral mouth complaints. After one hour, the patient seat on the chair with the head down, the saliva collected in the floor of the mouth and spited into the measuring tube. Then volume of the saliva was measured in milliliter per minute.

\section{RESULT}

Fifty patients with type $2 \mathrm{DM}$, that matched the criteria samples were found (36 male and 14 female). Most of patients with type $2 \mathrm{DM}$ were over than 60 years old (19 patients $-38 \%), 51-60$ years old were 17 patients (34\%), 40-50 years old were 14 patients $(28 \%)$. The suffering duration of DM less than 1 year consist of 10 patients (20\%), $1-5$ years was 19 patients (38\%), 6-10 years was 13 patients $(26 \%)$ and the suffering duration over 10 years was 8 patients $(16 \%)$.
Good regulation of fasting blood glucose level was found on 5 patients (10\%), moderate regulation was 14 patients (28\%), and bad regulation was 31 patients (62\%). While two hours post prandial blood glucose level with good regulation was found on 9 patients (18\%), moderate regulation was $6(12 \%)$ and bad regulation 35 patients $(70 \%)$

Thirty eight out of 50 patients $(76 \%)$ of type $2 \mathrm{DM}$ experienced xerostomia which saliva secretion less than $0.15 \mathrm{ml} / \mathrm{mint}$. Among the patients with xerostomia, six patients had suffered less than 1 year, 17 patients had suffered 1-5 years, 9 patients had suffered 6-10 years and 6 patients had suffered more than 10 years. From 38 patients which suffering xerostomia, 32 patients had bad regulation on fasting and the 2 hours post prandial blood glucose level. Five patients had moderate regulation and only one patient had good regulation on blood glucose level.

Table 2 showed, that suffering duration less than 1 year were 10 patients, and had experienced xerostomia were 6 patients $(12 \%)$, and all of the patients felt various subjective symptoms. Four patients had not experienced xerostomia, the two patients felt subjective symptoms and two others patients were not. In the group of suffering duration of 1-5 years were 19 patients and had experienced xerostomia were 17 patients (34\%), and all of the patients felt various subjective symptoms.

In the group of suffering duration of 6-10 years were found 13 patients, and felt subjective symptoms. The xerostomia is patients were 9 patients (18\%) and saliva secretion of the four patients were normal. Likewise, in the group of suffering duration over than 10 years were found 8 patients, six patients $(12 \%)$ were saliva secretion of less than normal. Either, the xerostomia patients or not, felt subjective symptom.

Table 1. Distribution of suffering duration, age, gender, saliva secretion, regulation of fasting blood glucose, and regulation 2 hours post prandial

\begin{tabular}{|c|c|c|c|c|c|}
\hline $\begin{array}{l}\text { Suffering } \\
\text { duration }\end{array}$ & Age (years) & Gender & $\begin{array}{l}\text { Saliva secretion } \\
\quad(\mathrm{ml} / \mathrm{mint})\end{array}$ & $\begin{array}{c}\text { Fasting blood glucose } \\
\text { level (mg/dl) }\end{array}$ & $\begin{array}{l}2 \text { hours-post prandial blooc } \\
\text { glucose level }(\mathrm{mg} / \mathrm{dl})\end{array}$ \\
\hline \multirow[t]{3}{*}{$<1$ years } & $40-50 \rightarrow 5$ & $10 \mathrm{px}: ð 7$ & $\geq 0.15 \rightarrow 4$ & Good $\rightarrow 2$ & Good $\rightarrow 1$ \\
\hline & $51-60 \rightarrow 3$ & 운 & $<0.15 \rightarrow 6$ & Moderate $\rightarrow 2$ & Moderate $\rightarrow 0$ \\
\hline & $>60 \rightarrow 2$ & & & $\mathrm{Bad} \rightarrow 6$ & $\mathrm{Bad} \rightarrow 9$ \\
\hline \multirow[t]{3}{*}{$1-5$ years } & $40-50 \rightarrow 2$ & 19 px : Љ 14 & $\geq 0.15 \rightarrow 2$ & Good $\rightarrow 2$ & Good $\rightarrow 5$ \\
\hline & $51-60 \rightarrow 7$ & 05 & $<0.15 \rightarrow 17$ & Moderate $\rightarrow 8$ & Moderate $\rightarrow 2$ \\
\hline & $>60 \rightarrow 10$ & & & $\mathrm{Bad} \rightarrow 9$ & $\mathrm{Bad} \rightarrow 12$ \\
\hline \multirow[t]{3}{*}{$6-10$ years } & $40-50 \rightarrow 5$ & $13 n$ & $\geq 0.15 \rightarrow 4$ & Good $\rightarrow 0$ & Good $\rightarrow 2$ \\
\hline & $51-60 \rightarrow 3$ & 13 & $<0.15 \rightarrow 9$ & Moderate $\rightarrow 2$ & Moderate $\rightarrow 4$ \\
\hline & $>60 \rightarrow 5$ & & & $\mathrm{Bad} \rightarrow 11$ & $\mathrm{Bad} \rightarrow 7$ \\
\hline \multirow[t]{3}{*}{$>10$ years } & $40-50 \rightarrow 2$ & & $\geq 0.15 \rightarrow 2$ & Good $\rightarrow 1$ & Good $\rightarrow 1$ \\
\hline & $51-60 \rightarrow 4$ & $8 \mathrm{px}: 07$ & $<0.15 \rightarrow 6$ & Moderate $\rightarrow 2$ & Moderate $\rightarrow 0$ \\
\hline & $>60 \rightarrow 2$ & 1 & & $\mathrm{Bad} \rightarrow 5$ & $\mathrm{Bad} \rightarrow 7$ \\
\hline \multirow[t]{3}{*}{$\mathrm{N}=50 \mathrm{px}$} & $40-50 \rightarrow 14$ & ภ̂ 14 & Normal 12 & Good $\rightarrow 5$ & Good $\rightarrow 9$ \\
\hline & $51-60 \rightarrow 17$ & +36 & Xerostomia 38 & Moderate $\rightarrow 14$ & Moderate $\rightarrow 6$ \\
\hline & $>60 \rightarrow 19$ & & & $\mathrm{Bad} \rightarrow 31$ & $\mathrm{Bad} \rightarrow 35$ \\
\hline
\end{tabular}


Table 2. Distribution of suffering duration, saliva secretion, and subjective symptom in the mouth

\begin{tabular}{|c|c|c|c|c|c|c|c|c|c|}
\hline $\begin{array}{l}\text { Suffering } \\
\text { duration }\end{array}$ & $\begin{array}{c}\text { Saliva } \\
\text { secretion } \\
\text { ml/mint }\end{array}$ & $\begin{array}{l}\text { Dryness } \\
\text { of the } \\
\text { mouth }\end{array}$ & $\begin{array}{l}\text { Dryness } \\
\text { at eating }\end{array}$ & $\begin{array}{c}\text { Difficulty } \\
\text { of } \\
\text { swallowing }\end{array}$ & $\begin{array}{c}\text { Needed } \\
\text { fluid for } \\
\text { swallowing }\end{array}$ & $\begin{array}{l}\text { Dryness } \\
\text { of the } \\
\text { mouth at } \\
\text { night }\end{array}$ & $\begin{array}{l}\text { Difficulty } \\
\text { of tasting }\end{array}$ & $\begin{array}{l}\text { Soreness of } \\
\text { the tongue }\end{array}$ & $\begin{array}{c}\text { Dryness } \\
\text { at } \\
\text { speaking }\end{array}$ \\
\hline$<1$ year & $\geq 0.15: 4$ & - & - & 1 & 1 & 1 & - & - & - \\
\hline 10 px $(20 \%)$ & $<0.15: 6$ & 4 & 4 & 2 & 2 & 2 & 1 & 2 & 2 \\
\hline $1-5$ years & $\geq 0.15: 2$ & - & 1 & 1 & 1 & - & - & - & - \\
\hline 19 px $(38 \%)$ & $<0.15: 17$ & 7 & 12 & 11 & 10 & 8 & - & 2 & 4 \\
\hline $6-10$ years & $\geq 0.15: 4$ & - & 2 & 3 & 3 & 1 & - & 1 & - \\
\hline 13 px $(26 \%)$ & $<0.15: 9$ & 5 & 7 & 4 & 4 & 7 & 1 & 1 & 1 \\
\hline$>10$ years & $\geq 0.15: 2$ & - & 1 & 1 & 1 & - & - & - & 1 \\
\hline 8 px (16\%) & $<0.15: 6$ & 4 & 5 & 6 & 6 & 6 & 1 & 1 & 6 \\
\hline \multirow{2}{*}{$\Sigma$} & $\begin{array}{l}\geq 0.15: \\
12(4 \%)\end{array}$ & - & 4 & 6 & 6 & 2 & - & 1 & 1 \\
\hline & $\begin{array}{l}<0.15: \\
38(76 \%)\end{array}$ & $20 \mathrm{px}$ & 28 & 23 & 22 & 23 & 3 & 6 & 13 \\
\hline
\end{tabular}

\section{DISCUSSION}

Approximate $80 \%$ to $90 \%$ of DM patients are type $2,{ }^{2}$ that was the reason why we chooce type 2 DM as sample, it can represent almost all patient with DM. The result of this study at Hajj Hospital Surabaya showed the prevalence of male patient was $72 \%$ and female $38 \%$. This was different from previous research that was done at Dr. Soetomo Hospital and Dr. Saiful Anwar Hospital, which the comparison between male by female patients were equal. ${ }^{7,8}$ One of the criteria sample of this study, was the women had not been menopause (even over 40 years old). Therefore, the women samples were less than men.

In this study on patients with type $2 \mathrm{DM}$, increased along the age and the result was similar with the epidemiological finding previously. ${ }^{9}$ According to Maitra \& Abbas, ${ }^{2}$ most of the patients with type 2 diabetes mellitus are (over 40 years old).

The suffering duration of this disease was measured from the initial diagnosis and treatment given as DM. The result, was very from 1 month until more than ten years. The characteristic feature of the most type $2 \mathrm{DM}$ is insulin resistance. ${ }^{3,4}$ Insulin resistance is defined as resistance to the effects of insulin on glucose uptake, metabolism or storage, and is frequently detected 10 to 20 years before the onset of DM in predisposed individual. ${ }^{2}$

According to the Perkeni, ${ }^{10}$ the criteria of good regulation fasting blood glucose level is $80-109 \mathrm{mg} /$ $\mathrm{dl}$, moderate regulation is $110-125 \mathrm{mg} / \mathrm{dl}$ and bad regulation is equal or higher $126 \mathrm{mg} / \mathrm{dl}$. Good regulation of two hours post prandial blood glucose level is $80-144 \mathrm{mg} / \mathrm{dl}$, moderate regulation is $145-179 \mathrm{mg} / \mathrm{dl}$ and bad regulation $\geq 180 \mathrm{mg} / \mathrm{dl}$.

Insulin is known as the most potent anabolic hormone, and principally has a metabolic function to increase the rate of glucose transport into certain cells in the body. These are the striated muscles including myocardium cell, and to a less extend adiposities representing collectively about two thirds of the entire body weight. Insulin resistance can decrease uptake of the glucose in muscle and adipose tissue and unable glucagons hormone to suppress hepatic gluconeogenesis, resulted the increase blood glucose level and in the long term would cause serious complication including macro and micro vascular disease. ${ }^{2}$

Saliva secretion equal $0.15 \mathrm{ml} / \mathrm{min}$ is the borderline of xerostomia. The two patients that were not experience xerostomia, one of them felt subjective symptoms. In these groups, the process of micro vascular glands disturbance might occured, but clinical sign had not revealed. That was proved, that some patients had subjective symptoms although saliva secretion was normal.

Most of the patients complained dryness of the mouth, dryness while eating, difficulty of swallowing, needed fluid for swallowing, dryness of the mouth at night. Some of them complained difficulty of tasting, soreness of the tongue and dryness while speaking. The longer suffering period of DM the more complication will appear.

Saliva is produced by salivary glands, the fluid formation in salivary glands occurs in the end pieces (acini) where serous cells produce a watery seromucous secretion and mucous cell produce a viscous mucin rich secretion. These secretions arise by the formation from blood in capillaries of interstitial fluid which is then modified by the end piece cells to produce the fluid which is secreted into the lumen. From the lumen it passes the ductal system where it is further modified. Most of the modification occurs in the striated duct. The composition of saliva is further modified in the excretory duct before it is finally secreted into the mouth. The blood supply to the glands also influences secretion. There is a concentration of capillaries around the striated ducts. The process of salivation indirectly dilates the blood vessels thus providing increased nutrition as needed. Salivary secretion is usually accompanied by a large increase in blood flow. ${ }^{11}$ An extensive blood supply is 
required for the rapid secretion of saliva, when in the blood supply is occurred disturbance as micro and macro vascular disease on DM therefore saliva secretion decreased. Moore and Vernillo said that blood glucose level concentration is significant correlation to salivary flow. ${ }^{12,13}$

The functions of saliva are not only protective, but also have other functions. Such as to coat mucosa and to protect against irritation, to assist smooth air flow, to produce speech and to swallow. ${ }^{11,14}$ If the saliva secretion is less than normal, it will the decrease the functions, finally subjective symptoms would appear.

According to this research, the prevalence of xerostomia on type 2 DM in Hajj Hospital Surabaya was high (76\%) and most of the patients with xerostomia $(84,21 \%)$ were in bad regulation of DM. Therefore, saliva can be used as the important indicator for serious systemic disease as diabetes mellitus.

\section{REFERENCES}

1. Tjokroprawiro A. Diabetes mellitus (Kapita Selekta 1997). PKB XII. Lab.UPF Ilmu Penyakit Dalam FK Unair-RSUD Dr. Soetomo, Surabaya. 1997. p. 3.

2. Maitra A, Abbas AK. The endocrine of the pancreas. In pathologic basic of disease. Pennsylvania: Elsevier Inc; 2005. p. 1189-205.

3. Ibsen OAC, Phelan JA. Oral pathology for the dental hygienist. $2^{\text {nd }}$ ed. Philadelphia: WB Saunders Co; 1996. p. 391-4.
4. Power, Alvin C. Harrison's. Principle of internal medicine. Vol. II. $16^{\text {th }}$ ed. New York: McGraw-Hill; 2005. p. 2152-80.

5. Wilkins EM. Clinical practice of the dental hygienist. $8^{\text {th }}$ ed. Philadelphia: Lippincot William \& Wilkins; 1999. p. 880-9.

6. Darby ML, Walsh MM. Dental hygiene theory and practice. Philadelphia: WB Saunders Co; 1995. p. 568, 814, 898-907, 922-3.

7. Harlina, Hernawan. Hubungan antara kadar glukosa darah dan kadar glukosa saliva pada penderita diabetes mellitus. Majalah Kedokteran Gigi (Dental Journal) 2003; 36(2):64-7.

8. Dewi AR. Prevalensi xerostomia pada penderita diabetes mellitus tipe 2 poli diabetes instalasi rawat jalan RSUD Dr. Saiful Anwar Malang. Skripsi. Surabaya: Fakultas Kedokteran Gigi Universitas Airlangga; 2005. p. 18-30.

9. Tjokroprawiro A. Garis besar kuliah diabetes mellitus. Surabaya: Lab. UPF Ilmu Penyakit Dalam FK Unair RSUD Dr. Soetomo; 1993. p. 2.

10. PERKENI. Petunjuk praktis pengelolaan diabetes mellitus tipe 2 . Pusat Diabetes dan Lipid. Universitas Indonesia; 2002. p. 1-10, 43-47.

11. Whelton H. Introduction the anatomy and physiology. In saliva and oral health. $2^{\text {nd }}$ ed. London: The British Dental Association; 1996. p. $1-7$.

12. Moore. Diabetes and oral health promotion: a survey of disease prevention behavior. Journal American Dental Association 2000; 13 (9):1333-41.

13. Vernillo A. Dental considerations for the treatment of patients with diabetes mellitus. Journal American Dental Association 2003; 134 (1):24S-33S.

14. Sreebny ML. Xerostomia: diagnosis, management and clinical complication.in saliva and oral health. $2^{\text {nd }}$ ed. London: The British Dental Association; 1996. p. 43-7. 